\title{
Lois Zamperini's American dreams as reflected in the film Unbroken
}

\author{
Masruriati Khairiah ${ }^{a, 1, *}$ \\ ${ }^{a}$ English Literature Departement Universitas Ahmad Dahlan \\ ${ }^{1}$ Masruriati@com.uad.ac.id*; \\ * corresponding author
}

Article history

Received 01-09-2020

Revised 19-10-2020

Accepted 20-10-2020

Keywords

American Dream

Motivation

Popular Culture

\begin{abstract}
In this undergraduate thesis describes about American dream and motivation theory. This is aiming at analyzing motivation's role in human life to fulfill their needs by focusing to the main character. The concept of American dream can be seen in Louis Zamperini as the main character of this film in principle of life. Hence, this undergraduate thesis has two main objectives to describe the Louis Zamperini's dreams and to analyze Louis Zamperini's motivation in his survival as the prisoner of Japan as reflected in the film Unbroken. This research is under a descriptive qualitative method. Therefore, library research is used for compiling both primary data and secondary data. The primary data is adopted from the film, meanwhile the secondary data refer to some sources, such as books, journals, articles, and on-line data from internet. Method of American studies as an interdisciplinary approach is also applied along with theories to analyze the problem formulation in this research. After the data are collected, they are analyzed by using the psychological study approach, and focuses on theory Hierarchy Needs of Abraham Maslow. Maslow's theory explained the description of motivation based on needs. The hierarchy dividing to physiological needs, safety needs, love needs, esteem needs, and needs for selfactualization. Then, the writer uses American dream concept such as the dream of good life, liberty, and pursuit of happiness. The results of this research, the researcher found that Louis Zamperini as the main character what he did in life, there is a motivation that supports him to reach his dream like other immigrants who came to America using this concept in general. The American dream and motivation are still adopted in some American films as popular culture. Hence, it proves that American dream still exists with different style like media of film.
\end{abstract}

This is an open access article under the CC-BY-SA license.

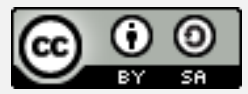

\section{Introduction}

Some people need multi-dimensional processes to get success in some aspects. Such condition will occur if the people start making preferences for their personal development. Therefore, people must set personality types to ensure the success of its motivational development. The above explanation brings some the reasons for the writer in choosing this subject. This film is one of true story one of National soldier of America in World War II. Then, this is a dedicated movie as a tribute National soldiers and one of them is Louis Zamperini.

In this research, the researcher tries to define how the character of Louis Zamperini in struggle of life, his passion to alive when the condition of World War II, how he reach his aim to pursuit his happiness and this character as the arrest man of Japan as the enemy of the United States in the film 
of Unbroken directed by Angelina Jolie. This film is one of best film which is awarded in 2014. In addition, the researcher using theory of motivation, which is that theory first major introduced by Abraham Maslow.

\section{Theorotocal Framework}

In this study "A theory describes a specific realm of knowledge and explains how it works." (Fry, 2012). Swanson said that theories as "an applied disciplines are realms of study and practice that are fully understood through their use in the functioning world". It another words that theories are very important in understanding a discipline of knowledge before practice in research and how to apply that theories itself (Review \& Science, 1997).

As well as some of definition above, the researcher uses some theories to support analysis of research. Some of theories that the researcher uses the psychological approach which is how show or describe how the main character to maintain his aim to reach happiness and two theories that contain about first theory is motivation theory which explains how the character of Louis Zamperini in pursuing his happiness and passion to alive when the condition of World War II and this character as the arrest man of Japan as the enemy of the United States in the film of Unbroken. The second theory (Brüne, 2005).

Which is Popular Culture theory which discuss about the reason of film as a media or one of product of the mass culture in modern eras and about how American popular culture spread some ideas as great nation (Jati Kusuma, 2019).

\section{American Popular Culture}

Popular culture can be identified with mass culture in modern era. The coming of the mass media to be commercial of culture and given huge impacts to our societies with rise to issues, interests, and many others themes which are still us until now (Potts, 2019). In other words, mass culture represents something new to society with display background and perspectives on popular culture so that the coming of mass media very influential to the society.

According to Strinati "Mass culture is therefore a culture which lacks intellectual challenge and stimulation, providing instead the undemanding ease of fantasy and escapism" (Nama, 2011). Such the writer said before, society must be clever in filter the media of mass culture, and it does not demand of audience think but they must be responses in perceive and critical thinking.

\section{Film as Popular Culture}

Popular culture is one that is very familiar to us. We probably consume lot of media content in the form of music, TV, film and the internet. Popular culture is very useful for the people make a kind of activity such as academic research, and helping them to think about the other information that can discussed. In this topic, the researcher focuses discuss about Film. Film are product of popular culture itself. Film are part our everyday life (Horbinski, 2019). This makes film and television part of our popular culture. Popular culture makes a sense not only how the audiences enjoy the product of popular culture, but also they can emphasize shape that taste and values in that media especially in the film. In the film, depend on audiences appreciating every single part of the story. Because film has various genre such as drama, comedy, history, love, action, etc.

\section{The Values of American Dream}

\section{a. The Dream of Good Life}

The American Dream has continued to become more and more materialistic. The value of people's success is not measured in their quality of life, but through the amount of property they have. According to High, "In the past many people came to the United States to leave the stratified European society. However, upward mobility is becoming increasingly difficult in the United States" (Worrell, 2015). The puritan who came to America to looking for a better life and one of the reason why they came is escape from poverty and hunger be sides separate from church.

b. Liberty 
One of the most important parts of the Declaration of Independence is its preamble and more specifically, certain phrases contained within the preamble. Thomas Jefferson does an excellent job of explaining why the colonies are doing the things they are doing, and is very clear in stating what he and his associates think are the "unalienable rights" of the American people (Worrell, 2015).

\section{c. The Pursuit of Happiness}

"American pursuit of happiness falls into two categories, first the religious hope and second the secular dreams. From the time of the first settlers through the colonial time, the revolution, the Civil War, up to modern time the American. Hhave a dream in pursuing happiness which is often called the American Dream."(Worrell, 2015). It means that of American people seek freedom of life to embrace some kinds of religion and belief something without oppression. They also want to express their feelings on their ideas and thought in public and freedom from poverty and suppression.

\section{Psychological Approach}

The term psychology (actually psychologia in Latin) was apparently first used around 1530 by German scholar. Phillip Melanchton, as a title for some lectures. It's originally meaning from the Greek psyche (or soul) and logos (or study) it was "the study of the soul". Later psyche became translated as "mind" rather than "soul"; and in this century, psychology was redefined as "the science of behavior" (Kasser \& Ryan, 1993). Psychologists attempt to systematically ask and answer question about why people act think, and feel the way they do (Clack, 2012).

\section{Theory of Human Motivation}

Motivation theory is not synonymous with behavior theory. Motivation is one of the forces that lead to performance. Motivation is defined as the desire to achieve a goal or a certain performance level, leading to goal-directed behavior. The motivations are only one class of determinants of behavior. While behavior is almost always motivated, it is also almost always biologically, culturally and situationally determined as well (Jandevi, 2019).

"Maslow postulated that people begin development with basic needs (motives) that are not noticeably different from animal motivation" (de Ridder, 2015). As they mature and as their lowerorder needs are satisfied, people develop more uniquely human motivations. Thus, motivation changes as we progress upward through a hierarchy needs, or motives. This hierarchy consists of five levels: four levels of deficiency motivation and a final, highly developed level called being motivation, or self-actualization.

\section{a. Biological and Physiological Needs}

The most basic needs of any person are physiological needs, including food, water, oxygen, sex, maintenance of body temperature, excretion and others. Physiological needs are the most prepotent of all. "Perpetually hungry people are motivated to eat not to make friends or gain self-esteem" (Park \& Corn, 2017). They do not see beyond food, and as long as this need remains unsatisfied, they primary motivation is to obtain something to eat.

\section{b. Safety Needs}

As the physiological needs become increasingly satisfied, the next level in the hierarchy gradually emerges as a motivator. These safety needs involve the quest for an environment that is stable, predictable, and free from anxiety and chaos (Brown, 2008). For example a young child may seek reassurance and protection after being frightened by a sudden loud noise or injury. Or an adult in the grip of safety needs may pursue a tenured professorship, amass a substantial saving account, or constantly prefer the familiar and routine to the unknown. 


\section{c. Belongingness and Love Needs}

Once the physiological and safety needs have been more or less satisfied, the belongingness and love needs come to the forefront as motivators. The individual now hungers for affectionate relationships with friends, a sweetheart or spouse and or offspring.

d. The Esteem Needs

To the extent the people satisfy their love and belongingness needs, they are free to pursue esteem needs, which include self-respect, confidence, competence, and the knowledge that others hold them in high esteem. Maslow identified two levels of esteem needs- reputation and self-esteem. Reputation is the perception of the prestige, recognition, or fame a person has achieved in the eyes of others, whereas self-esteem is a person's own feelings of worth and confidence (Kahneman \& Tversky, 1973).

\section{e. The Needs for Self-Actualization}

Self-actualization include self-fulfillment, the realization of all one's potential, and a desire to become creative in the full sense of the word. People who have reached the level of selfactualization become fully human, satisfying needs that others merely glimpse or never view at all. They are natural in the same sense that animals and infants are natural; that is, they express their basic human needs and do not allow them to be suppressed by culture/ (Center, 2005).

Self-actualizing people maintain their feelings of self-esteem even when scorned, rejected, and dismissed by other people. In other words, self-actualizers are not dependent on the satisfaction of either love or esteem needs; they become independent from the lower level needs that gave them birth.

\section{Method}

In this To analyze the data, the researcher uses qualitative method. Qualitative method means describing the discussion in detail. According to George R. Taylor, "In qualitative research, data are usually expressed in words, however in some instances, hypotheses may be used. Descriptive statistics are frequently used to display some data, such as graphs, charts, percentiles, and measures of central tendency" (Ruch \& Taylor, 2015).

Based on the explanation above, descriptive technique is away use in this research to get cleaner information about the data that suitable with the topic of the study. The study that will be discussed is about dream and motivation of the Main Character Louis Zamperini as Reflected in the Film Unbroken.

a. Data and Source of Data

a) Main Data

Unbroken is the main source for the researcher to get almost all of data. Every scenes and dialogues on the movie reflects the happened in America that show American Dream, American history in general especially in World War II, and motivation theory of main character in the film Unbroken.

\section{b) Supporting Data}

In this research the researcher uses some Medias to figure out more information relating on the theme through internet, articles, newspapers, and books to analyze motivation of main character in fighting against Japan in the film Unbroken. There are two kinds of method to analyze the data; those are qualitative and quantitative method. Qualitative research is many things at that same time. It is multi paradigmatic in focus (Whittemore \& Knafl, 2005). 


\section{c) Technique of Collecting Data}

This method does not require a large sample or with materials that complicated, unlike quantitative data that requires a complicated way and require a large sample. Qualitative research is by definition exploratory, and it is used when we do not know what to expect, to define the problem or develop an approach to the problem. It's also used to go deeper into issues of interest and explore nuances related to the problem at hand (Neuman, 2014). Common data collection methods used in qualitative research is focus groups, triads, dyads, in depth. interviews, uninterrupted observation, bulletin boards, and ethnographic participation/observation. The data which is collected is classified based on the Unbroken film.

\section{Method of Analyzing Data}

In analyzing data, the researcher uses qualitative method that uses descriptive presentation of analysis. This suitable method to the problems that are going to be analyzed. This will give the true and clear information to answer the problem. There are some steps to process the data: Description Phase and Interpretation Phase (Neuman, 2014).

\section{Results and Discussion}

A. The Concept of American Dreams

\section{The Dream of Good Life}

Few people in America hope of good life in their live. The puritan who came to America looking for a better life. And one of the reason why they came to America escape from poverty, scolding and insults from other people who like criticize someone else. Every people have a dream to a good life, have purpose, ambition, and aim in their life to be a good person or success so that People who do not know ourselves are not arbitrary in criticizing and judging. Olympics Radio Announcer : In an astounding performance, Negro American Jesse Owens from Ohio State has won four gold medals in the 100 meter, the 200 meter, the long jump and the 400 meter relay. Next up, the 5000 meter with America's record-breaking Don Lash leading the American team along with newcomer Louis Zamperini.

Olympics Radio Announcer : And we start the last lap. The Finns seem to be in control. It doesn't look like Don Lash is gonna bring home the medal for USA. There seems to be some movement back in the pack. Yes, that's Zamperini overtaking Norway's Rolf Hansen. He seems to have some gas in reserve. He really is making up some time. HÖckert and Lehtinen will be one and two. But look at that Zamperini! He's got Don Lash in his sight. The great Don Lash is not gonna be the first American folks. He's high school kid Zamperini pushing past the record-breakers on this fields! I have not seen that! I have not seen that! That final lap folks, the record for that was 69.2 seconds. Zamperini just did it in 56 seconds. (Source: Unbroken, 2014Scene 00: 28: 20 directed by Angelina Jolie).

In this scene, the main character Louis Zamperini always get unfair treatment from Native of America, because he and his family come from Italy who migrated to America and had same hope with other immigrant.

\section{Liberty}

The writer saw the effort of Louis Zamperini and friends to maintain their liberty and freedom from captives of Japan. First, Louis and all prisoners tried to collect all data and news about Japan mission as long as they were in the quarantine barrack in Japan. Louis himself did not want to be humiliated by another country that insulted his country. Second, Louis also wants to express his feeling as long as to be prisoner of Japan, he get worst treatment. Then, the researcher wants to give example how Louis expressed his upset, his anger over the movie scene. 


\section{The Pursuit of Happiness}

Pursuit of happiness is the fundamental right to freely seek joy and pleasure and live life in a way that makes us happy. Happiness is a state well-being that living a good life and deep satisfaction. American seek the happiness from freedom without oppression from other person. And they, believe that freedom not only having good life but also freedom from thought and poverty so that the writer believe that it all encompasses in pursuing of happiness. In this case, the writer also talk about how Louis Zamperini's struggle in pursuing his happiness although many obstacles. (1) Dad: Louis, (2) Pete: Oh my God, Look at you! (Hug Louis), (3) Louis : Oh Mama (hug his mama).

In the scene above upon delivery of happiness of the main character because his aim to reach in his home. He became a Japanese prisoner at the time of World War II. The land he missed as to be a prisoners of Japan. Finally what he dreamed about America, liberty, wants to freedom, Louis can back safely. His parents and family can he meet again.

\section{B. Human Motivation Hierarchy}

\section{1) Biological and Physiological Needs}

The researcher wants to show and talk about Louis facing obstacles during stranded at sea as long as 47 days. They save on existing food and beverage supplies. But it was not enough, because they must have to survive any way they are. The researcher shows some scenes that describe how they survive at the sea below so that in this case to be clear that human needs such as, food, water, and oxygen. Because it was human being.

\section{2) Safety Need}

If a person feels threatened, needs further up the pyramid will not receive attention until that need has been resolved. These needs have to do with our natural desire for a predictable, orderly world that is somewhat within our control. The writer wants to show that in this case human not only needs physiological, but also if they not feel frightened, then they feel stress so that they will be sick even cause of not living a safe area.

Louis and the other prisoners get In-appropriate treatment from Japan as long as in prisoners of war. All of prisoners sleeping in an uncomfortable place, where the place is very slum. They also always feel threatened if the Japanese troops could have been and whenever they were killed by them. The writer also saw Louis Zamperini's struggle in maintain from threat of Japan. Louis's effort to always feel safely Louis wants kill all of Japanese, although Louis will die shoot by Japan. But, he thinks that survived until the end of war, he would like to kill them. He believes that their Nation will won this war, and Japanese will surrendered to America.

\section{3) Belongingness and Love Needs}

The researcher found one scene that strongly describe how love needs come to the motivators in this life especially for Louis Zamperini. That's why Louis becomes the number one American runner because Pete as his brother always gives support although once Louis never heard anyone's words. Because of his brother's support and the prayers of his parents, Louis became successful in becoming a member of the American military.

The main character Louis Zamperini went to German to follow Olympic for America and then Pete, his old brother always give support, love, believe that Louie can do everything although he got a pain. Pete is one of influential people in Louis's life, because he is a person who saw his younger brother's ability. Pete is a figure who is always on the side of Louis, always accompanies Louis when Louis follows every run.

4) The Esteem Needs

The researcher analyze the main character Louis Zamperini in maintain his prestige and how the main character wants the other person there is a respect to him below. Louis get special offer from japan to be free from captive. But with one agreement, Louis must say again in Radio something that is not true based on the facts. Then, Louis disagree because he promised to be a good military of American and not betrayed of his country also choose back to the camp. 
5) The Needs for Self-Actualization

The researcher analyzes Louis Zamperini's motivation becoming Olympic runner and American military are at first Louis Zamperini is a person who always gets bullying from his friends, then Louis fading and run stay away from his friends. Louis also get protection from local police when he beaten by his friend. Pete as Louis's brother often saw his young brother always run for being chased by people who wanted to hit him.

\section{Conlusion}

In this research the researcher saw that America has adopted American dream that is a way of American on how they reached their aim of good life, liberty and pursuit their happiness in life. American dreams come because the immigrants who come to America have new dreams and hopes. It means that every person has a concept to choose how they live in their country with freedom to express opinion to the public freely without oppression from other. Human also has a right where they can life as what they like and the life they choose as they wish.

\section{References}

Brown, C. (2008). Developmental psychology. In Developmental Psychology. https://doi.org/10.4135/9781446214633

Brüne, M. (2005). "Theory of mind" in schizophrenia: A review of the literature. Schizophrenia Bulletin. https://doi.org/10.1093/schbul/sbi002

Center, P. W. (2005). Writing a Psychology Literature Review. Current Directions in Psychological Science.

Clack, B. (2012). Psychology. In The Routledge Companion to Theism. https://doi.org/10.4324/9780203123294

de Ridder, D. (2015). Health Psychology. In International Encyclopedia of the Social \& Behavioral Sciences: Second Edition. https://doi.org/10.1016/B978-0-08-097086-8.14099-1

Fry, P. H. (2012). Theory of literature. In Theory of Literature. https://doi.org/10.2307/585969

Horbinski, A. (2019). Convergence Culture. In The Blackwell Encyclopedia of Sociology. https://doi.org/10.1002/9781405165518.wbeos1270

Jandevi, U. (2019). Communication strategy to improve women's political participation in Indonesia. International Journal of Communication and Society, 1(2), 68-81. https://doi.org/10.31763/ijcs.v1i2.46

Jati Kusuma, M. I. (2019). Messages of parents affection for children in the movie bulan terbelah di langit amerika. International Journal of Communication and Society, 1(2), 89-96. https://doi.org/10.31763/ijcs.v1i2.47

Kahneman, D., \& Tversky, A. (1973). On the psychology of prediction. Psychological Review. https://doi.org/10.1037/h0034747

Kasser, T., \& Ryan, R. M. (1993). A Dark Side of the American Dream: Correlates of Financial Success as a Central Life Aspiration. Journal of Personality and Social Psychology. https://doi.org/10.1037/00223514.65.2.410

Nama, A. (2011). Super black: American pop culture and black superheroes. In Super Black: American Pop Culture and Black Superheroes. https://doi.org/10.5860/choice.49-4844

Neuman, W. L. (2014). Social Research Methods: Quantitative and Qualitative Approaches. In Pflege aktuell (Vol. 57). https://doi.org/10.2307/3211488 
Park, G. H. M., \& Corn, A. A. (2017). Positive psychology. In Applied Exercise Psychology: The Challenging Journey from Motivation to Adherence. https://doi.org/10.4324/9780203795422

Potts, T. (2019). Popular culture. Year's Work in Critical and Cultural Theory. https://doi.org/10.1093/ywcct/mbz018

Review, L., \& Science, P. (1997). Chapter 3 3. Review Literature And Arts Of The Americas.

Ruch, G. W., \& Taylor, G. (2015). Accounting conservatism: A review of the literature. Journal of Accounting Literature. https://doi.org/10.1016/j.acclit.2015.02.001

Whittemore, R., \& Knafl, K. (2005). The integrative review: Updated methodology. Journal of Advanced Nursing. https://doi.org/10.1111/j.1365-2648.2005.03621.x

Worrell, J. (2015). The American dream. European Pharmaceutical Contractor. https://doi.org/10.7748/ns.19.6.26.s45 